Stručni članak

Primljeno: travanj, 2020.

Prihvaćeno: listopad, 2021.

UDK: $613.8: 794.9$

\section{OTUĐENJE OD RODITELJA I OBITELJSKA MEDIJACIJA}

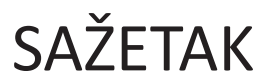

$S$ povećanjem broja i intenziteta sporova vezanih $u z$ ostvarivanje roditeljske skrbi, porastao je i broj djece koja tijekom tih postupaka pod utjecajem jednog roditelja odbacuju drugog roditelja i njegovu obitelj. Takvo je ponašanje prvi opisao Gardner 1985. godine nazivajući ga sindromom otuđenja od roditelja. Koncept se otad razvija doprinosima drugih stručnjaka te se sada naziva otuđenje od roditelja čiji su uzroci, znakovi i mogući pristupi tretmanu iscrpno opisani. Ukoliko izostane pravodobna i adekvatna pomoć, može doći do problema u socijalnom i psihičkom funkcioniranju, te psihogenih smetnji kod otuđene djece. Obiteljski medijator educiran o ovom problemu može doprinijeti njegovom ranom otkrivanju i pružanju adekvatne pomoći jer on može prepoznati problem i uputiti roditelje na sud ne gubeći vrijeme na obiteljsku medijaciju u slučajevima u kojima je to neadekvatna intervencija. Cilj ovog rada je prezentirati spoznaje o otuđenju od roditelja i pojasniti ulogu obiteljskog medijatora u procjeni i tretmanu istog.

UVOD

U razvedenim, kao i u cjelovitim obiteljima, uzajamna podrška, dosljedna disciplina, jasna komunikacija i dnevna rutina vode uspješnoj prilagodbi djece, dok roditeljski sukob, nedjelotvorna disciplina i konkurentni savezi uzrokuju pro-

1 Martina Protulipac, univ. spec. mediat., dipl. socijalna radnica, e:mail:martina. protulipac@gmail.com
DOI 10.3935/ljsr.v28i2.376

Martina Protulipac ${ }^{1}$

https://orcid.org/0000-0003-

4871-3424

Centar za socijalnu skrb

Duga Resa

Ključne riječi:

otuđenje od roditelja,

obiteliska medijacija,

visokokonfliktni razvod, manipulacija,

prevencija i tretman 
bleme prilagodbe kod djece (Teyber, 2001.). Prema Teyber (2001.), pojava problema kod djece kao posljedica razvoda primarno ovisi o četiri odrednice.

1. Izloženost roditeljskom konfliktu snažno utječe na psihosocijalni razvoj i prilagodbu djece, a za djecu je najteži aspekt roditeljskog sukoba manipulacija njima i ocrnjivanje drugog roditelja koje se smatra emocionalnim zlostavljanjem.

2. Roditelji se nakon razvoda nose s vlastitim problemima, što može rezultirati neadekvatnim roditeljskim postupanjem.

3. U najboljem je interesu djece da zadrže bliskost s oba roditelja. No, nakon razvoda jedan roditelj često sabotira odnos drugog roditelja s djetetom, tjerajući dijete da bira između roditelja što uzrokuje sukob lojalnosti, trajne psihološke probleme i probleme u ponašanju.

4. Parentifikacija, odnosno preuzimanje roditeljske uloge od strane djeteta posljedica je pretjeranog oslanjanja roditelja na dijete, uslijed čega djetetove emotivne potrebe ostaju zanemarene. Takva djeca imaju osjećaj pretjerane odgovornosti za druge, tjeskobe ako moraju tražiti pomoć, te krivnje. Stavljaju potrebe drugih ispred vlastitih. U odrasloj dobi teško uspostavljaju ravnopravan ljubavni odnos, već mogu uspostaviti ljubavni odnos s partnerom ovisnim o njima ili izbjegavati intimnost kroz promiskuitet (Teyber, 2001.).

U Republici Hrvatskoj do porasta broja razvoda, te širenja i prepoznavanja pojave otuđenja djece od roditelja došlo je kasnije nego u SAD-u pa imamo manje stručne literature i provedenih istraživanja tog problema. Stoga ovaj rad objedinjuje različite spoznaje o otuđenju od roditelja kako bi se doprinijelo educiranju stručnjaka, a time i pravodobnom prepoznavanju i adekvatnom tretmanu u slučajevima u kojima je došlo do otuđenja. Ciljevi i svrha ovog rada su: (1) objediniti istraživanja i spoznaje o otuđenju od roditelja kroz sažet prikaz njegove konceptualizacije, kao i kritika kasnijeg razvoja tog koncepta; (2) opisati kako nastaje otuđenje od roditelja i koji su znakovi istog te iznijeti smjernice za procjenu i tretman otuđenja i (3) pojasniti ulogu obiteljskog medijatora u prepoznavanju i intervenciji u slučajevima otuđenja.

\section{KONCEPTUALIZACIJA OTUĐENJA OD RODITELJA}

Gardner (1991.) je 1985. godine prvi definirao sindrom otuđenja od roditelja kao ponašanje djeteta koje pod utjecajem jednog roditelja odbacuje drugog prema kojem neopravdano izražava mržnju bez krivnje za takvo ponašanje koje pravda apsurdnim objašnjenjima. Najsporniji je aspekt Gardnerove konceptualizacije korištenje termina sindrom jer isti još nije prihvaćen kao dijagnoza te se danas koristi neutralniji termin otuđenje od roditelja. Nicholas (1997., prema Conway Rand, 1997.b) je utvrdio da 
postoji značajna veza između otuđujućeg ponašanja otuđitelja i pojave otuđenja kod djece, dok ista ne postoji između otuđenja djeteta i osobina otuđenog roditelja. $U$ oko 1/3 slučajeva utvrđeno je otuđujuće ponašanje jednog roditelja, koje je u oko 1/4 slučajeva utjecalo i na preporuke stručnjaka. Događa se, naime, da stručnjaci koji nemaju dovoljno spoznaja o ovom problemu daju neadekvatna mišljenja i preporuke sudu jer, primjerice, pristrano prikupljaju i interpretiraju podatke ili preporučuju neučinkovite intervencije kojima se otuđenje produbljuje.

Kopetski (1998., prema Rand, Rand, R. i Kopetski, 2005.) definira otuđenje od roditelja kao psihosocijalnu patologiju u kojoj roditelj dijeli svoje negativne stavove o drugom roditelju s djetetom, sve dok ih dijete ne usvoji kao vlastitu verziju istine, a otuđitelj postigne otuđenje. Clawar i Rivlin (2001., prema Warshak, 2003.) su na uzorku od 700 obitelji u razvodu utvrdili da je $80 \%$ roditelja u postupku razvoda »ispiralo mozak «² djece, od čega je $20 \%$ njih to činilo barem jednom dnevno. Clawar i Rivlin (1991., prema Conway Rand, 1997.a) smatraju da »ispiranje mozga« dovodi do teškog otuđenja od roditelja utjecajem roditelja na dijete.

Grupa stručnjaka predložila je 2008. godine uvrštavanje otuđenja od roditelja u DSM-V. Prijedlog je odbijen zbog nedostatka informacija o valjanosti dijagnoze, pouzdanosti dijagnostičkih kriterija i učestalosti (Bernet i sur., 2010.). Prijedlog za ICD-11 (Međunarodna klasifikacija bolesti) sadržavao je više informacija te više od 600 referenci iz stručne literature širom svijeta. Sam broj referenci i konzistentnost neovisnih opažanja upućuje na široko prihvaćanje otuđenja od roditelja kod stručnjaka. DSM-V i ICD-11 već sadrže klinički značajne poremećaje u funkcioniranju kao posljedice uzorka interakcija između roditelja i djece, što se dijelom preklapa s otuđenjem od roditelja. Također, s obzirom da otuđenje od roditelja može ozbiljno narušiti razvoj privrženosti, ono se može smatrati poremećajem privrženosti. Otuđenje od roditelja još nije prihvaćeno kao zasebna dijagnoza u Dijagnostičkom i statističkom priručniku za mentalne poremećaje (DSM-V) pa se u praksi najčešće dijagnostički definira kao psihološko ili emocionalno zlostavljanje koje je kao širi pojam uključeno u DSM. Bernet i sur. (2010.) definiraju otuđenje od roditelja kao mentalno stanje u kojem dijete stvara čvrst savez s jednim roditeljem i neopravdano odbacuje drugog, do čega obično dolazi tijekom visoko konfliktnog razvoda.

Bernet i Baker (2013.) tvrde da bi prihvaćanje otuđenja od roditelja kao dijagnoze omogućilo ranije prepoznavanje problema jer bi stručnjaci bili bolje educirani, a istraživači bi razvili tretman utemeljen na dokazima, čime bi se umanjile i zlouporabe na sudu.

2 »Ispiranje mozga« definirali su kao proces tijekom kojeg dijete prihvaća i nadograđuje sadržaj i vjerovanja koja mu otuđitelj prenosi o drugom roditelju. Taj proces uključuje ponavljanje tih sadržaja i vjerovanja ili ključnih riječi koje se na njih odnose sve dok dijete s njima ne uskladi vlastito ponašanje i stavove (Conway Rand, 1997.a). Uvjet za »ispiranje mozga« je izolacija koja stvara ovisnost i onemogućuje izlaganje drugačijim perspektivama i iskustvima koja bi se su protstavila ocrnjivanju (Warshak, 2008.). 
Boch-Galhau (2018.) definira otuđenje od roditelja kao neopravdano odbacivanje roditelja od strane izmanipuliranog djeteta, a smatra ga teškim psihološkim zlostavljanjem djece s dugoročnim psihofizičkim posljedicama.

\section{Kako dolazi do otuđenja i koji su znakovi istog?}

Visokokonfliktni razvodi povećavaju rizik nastanka otuđenja od roditelja jer što sukob duže traje izglednije je da će roditelji u nj uključiti i djecu, nakon čega se ona ne mogu uspješno prilagoditi bez zauzimanja strana (Conway Rand, 1997.a). Warshak (2008.) smatra da do otuđenja od roditelja dovode četiri skupine uzroka: otuđujuće ponašanje otuđitelja, djetetov doprinos, reakcija otuđenog roditelja i okolnosti razvoda. Clawar i Rivlin (2013., prema Warshak, 2015.) smatraju da je otuđiteljevo manipuliranje primarni uzrok otuđenja te takvo ponašanje smatraju emocionalnim zlostavljanjem.

Dijete stvara savez s otuđiteljem iz tri glavna razloga: da zaštiti otuđitelja kojeg vidi kao slabijeg; da manipuliranjem sukobom izbjegne nemoć i stekne kontrolu; adolescent da stekne slobodu oslobađanjem od strožeg roditelja, što dodatno pogoršava probleme u ponašanju djeteta i stres u konfliktnoj situaciji (Rand, 1997.b, prema Vassiliou i Cartwright, 2001.). Johnston (1993., prema Conway Rand, 1997.b) je utvrdila da djeca snažnim savezima štite slabijeg roditelja, izbjegavaju bijes moćnijeg i gubitak roditelja koji se njima manje bavio. Baker (2012., prema Woodall, 2014.) tvrdi da otuđena djeca vrlo vjerojatno žele da im netko pomogne, iako su njihove izražene želje često suprotne.

Prema Kelly i Johnston (2001.), dijete reagira na otuđujuća ponašanja roditelja ovisno o psihičkim, kognitivnim i razvojnim karakteristikama te vanjskim faktorima. Za odbacivanje i moralnu osudu roditelja nužna je određena zrelost pa je otuđenje rijetko teško prije sedme godine. Djeca te dobi brzo zaboravljaju optužbe i vole društvo drugog roditelja kad otuđitelj nije prisutan, no pod većim su rizikom od kasnijeg razvoja teškog otuđenja koje je najčešće u dobi od 9 do 15 godina. Za djecu može biti lakše popustiti pritisku nego podnositi tjeskobu roditeljskog sukoba i pritisak otuđitelja (Kelly i Johnston, 2001.). Kada se pokrene interakcija između otuđitelja i djeteta, otuđenje se samo pojačava jer se otuđitelj i dijete međusobno podupiru (Cartwright, 1993.). Što se lošije dijete ponaša prema otuđenom roditelju, to više sebe uvjerava da je on to zaslužio čime se štiti od unutarnjeg nesklada, a otuđenje se produbljuje. Ocrnjivanje, blaćenje i »ispiranje mozga«, ako se ne zaustave, dovode do poremećenih odnosa djece s drugim roditeljem ili čak njihova prekida (Warshak, 2008.).

Warshak (2008.) opisuje načine na koje otuđitelj potiče otuđenje, primjerice: manipuliranje imenima, korištenje selektivne pažnje i ambivalencije u odnosu roditelja 
i djeteta, izostavljanje konteksta ponašanja drugog roditelja pri njegovom prosuđivanju, pretjerivanje, laganje, revidiranje povijesti, pretjerano ugađanje, zadiranje u vrijeme i odnos s drugim roditeljem i slično. Ponekad se koriste preseljenjem ili čak otmicom djeteta. Otuđiteljeva obitelj može se pridružiti ocrnjivanju, a i stariji brat ili sestra »ispranog mozga« može održavati otuđenje kod mlađeg tijekom posjeta drugom roditelju. »Ispiranje mozga« završava "programiranjem « djece da se opiru pokušajima poništavanja istog, čime se dječji um zatvara za dokaze koji bi mogli poništiti otuđenje. Kada do toga dođe, otuđitelj može umanjiti ocrnjivanje i pretvarati se da podržava odnos djeteta s drugim roditeljem, ali da ga dijete samo odbacuje (Warshak, 2008.).

Manipulacijom se može znatno utjecati na odrasle, a djeca su još podložnija takvom utjecaju zbog nepotpuno razvijenih kognitivnih sposobnosti i potpune ovisnosti o roditelju. U slučajevima otuđenja česte su lažne optužbe o zlostavljanju, zanemarivanju i/li nasilju. Bitno je razlikovati lažne od neutemeljenih optužbi. Lažne optužbe iznosi otuđitelj iako je svjestan da nisu istinite. Neutemeljene optužbe iznosi roditelj koji vjeruje da su istinite zbog brige za dijete uslijed određenih ponašanja ili iskaza djeteta. Kopetski (1998.a) ističe da je roditeljima koji iznose neutemeljene optužbe drago kada se pokaže da djeca nisu zlostavljana, nakon čega potiču kontakt s drugim roditeljem. Otuđitelja koji iznosi lažne optužbe takvo otkriće ljuti te on traži drugo mišljenje dok ne dokaže da je u pravu. Buljan Flander (2010., prema Buljan Flander, Jelić Tuščić i Matešković, 2014.) upozorava da su lažne optužbe o zlostavljanju djece posebno opasne jer prisiljavaju stručnjake da promptno reagiraju ograničavanjem kontakata, a pomna procjena situacije vrši se tek kada se poduzmu propisane mjere za zaštitu djece.

\section{Obilježja otuđene djece}

Gardner je identificirao osam znakova otuđenja od roditelja prisutnih kod otuđene djece:

- kampanja ocrnjivanja roditelja

- banalna objašnjenja za odbacivanje roditelja

- manjak ambivalencije, odnosno doživljaj jednog roditelja potpuno pozitivnim, a drugog potpuno negativnim

- poricanje tuđeg utjecaja, odnosno tvrdnja da su sami odlučili odbaciti roditelja

- nekritično podupiranje otuđitelja u roditeljskom sukobu

- odsustvo krivnje zbog okrutnog tretiranja otuđenog roditelja

- posuđeni scenariji, poput opravdavanja odbacivanja otuđenog roditelja sjećanjima koja ne mogu biti njihova 
- rasprostiranje neprijateljstva na prijatelje i/li obitelj otuđenog roditelja (Warshak, 2008.).

Darnall (1998., prema Bernet i sur., 2010.) navodi da i blaga otuđujuća ponašanja roditelja kod djece izazivaju teškoće u učenju, koncentraciji, opuštanju, odnosima s vršnjacima, probleme u ponašanju, pa i tjelesne simptome. Posljedice otuđenja su dugoročne.

Johnston (2005., prema Bernet i sur., 2010.) smatra da je kod otuđene djece češća emotivna ovisnost, smanjena socijalna kompetentnost, problemi sa samopoštovanjem, smanjen kapacitet za testiranje stvarnosti i ambivalentnost te sklonost čvrstoj prepletenosti ili napuštanju u odnosima s drugima. Zbog polariziranog viđenja roditelja otuđena djeca doživljavaju svijet »crno-bijelim«, teže perfekcionizmu i teško podnose neuspjeh (Steinberg, 2006., prema Buljan Flander, Jelić Tuščić i Matešković, 2014.). Boch-Galhau i Kodjoe (2006.b, prema Bernet i sur., 2010.) navode strah, ovisnost i identifikaciju s otuđiteljem kao znakove otuđenja kod djece, koje uspoređuju sa Stockholskim sindromom i kultovima.

U tzv. rasprostiranju neprijateljstva otuđena djeca odbacuju svakog tko je povezan s otuđenim roditeljem. Prema Bernet i Baker (2013.), zlostavljana djeca često sebe krive za zlostavljanje kako bi mogla očuvati odnos s roditeljem koji ih zlostavlja. Stoga je rasprostiranje neprijateljstva, prema Warshak (2008.), jedan od najboljih pokazatelja za razlikovanje otuđene djece od djece koja reagiraju na zlostavljanje udaljavanjem od roditelja zlostavljača. Ono pokazuje da je otuđenje od roditelja neovisno o ponašanju otuđenog roditelja i da otuđena djeca kategoriziraju sve kao prijatelje ili neprijatelje. Iz racionalnog razgovara, kritike ili kazne za svoje ponašanje, otuđena djeca zaključuju da su neshvaćena i da je sugovornik zaslijepljen (Warshak, 2008.).

S obzirom da otuđitelj ne odobrava pozitivne stavove i osjećaje prema drugom roditelju, dijete ih pred njim skriva, zbog čega se osjeća krivim (Stahl, 2007., prema Buljan Flander, Jelić Tuščić i Matešković, 2014.). Zbog potiskivanja emocija djeca razvijaju psihogene smetnje (glavobolja, bol u trbuhu...), povlače se ili postaju depresivna (Steinberg, 2006., prema Buljan Flander, Jelić Tuščić i Matešković, 2014.).

Otuđena djeca često razvijaju anksioznu privrženost, odražavaju osobnost i iskrivljene percepcije otuđitelja te pokazuju simptome separacijske tjeskobe dugo nakon dobi u kojoj je to uobičajeno (Kopetski, 1998.b). Proces otuđenja uči ih zanemariti neugodne informacije umjesto ispraviti nesporazume pa su sklona rigidnosti i odbacivanju informacija koje ne potvrđuju njihove ideje (Kopetski, 1998.b).

Prema Teyber (2001.), djeca koja imaju moć otjerati roditelja precjenjuju vlastitu važnost i mogućnost utjecaja pa i u odrasloj dobi imaju nerealna očekivanja od sebe zbog čega se često osjećaju nedoraslima samonametnutim nerealnim očekivanjima. Otuđena djeca imaju dozvolu da budu nepristojna prema drugom roditelju, što utje- 
če na njihovu društvenu prilagodbu jer uče ne poštovati autoritete. U odrasloj dobi njihova manipulativnost, egocentričnost i neprihvaćanje granica često dovode do problema u svijetu rada i antisocijalnog ponašanja (iskorištavanje drugih, nasilničko ponašanje...) (Teyber, 2001.).

Dijete se identificira s oba roditelja te, ako jedan roditelj ocrnjuje drugog, učinak je isti kao da to čini izravno djetetu (Teyber, 2001.). Prema Baker i Ben-Ami (2011., prema Buljan Flander i sur., 2014.), ocrnjivanjem drugog roditelja djetetu se prenosi poruka da ga roditelj ne voli, zbog čega se dijete osjeća nevoljeno i nevrijedno ljubavi, što često dovodi do slabog samopouzdanja.

Baker (2005.a, prema Bernet i sur., 2010.) je utvrdila da osobe koje su u djetinjstvu bile otuđene od roditelja: imaju nisko samopoštovanje do granice mržnje prema sebi, da ih je 70\% iskusilo veće depresivne epizode, da oko 1/3 ima problema s alkoholom i/li drogom, da imaju manje povjerenja u sebe i druge, da ih je $50 \%$ otuđeno od vlastite djece, a 2/3 razvedeno. Otuđena djeca vjerojatnije će i sama otuđivati vlastitu djecu od drugog roditelja nakon vlastitog razvoda (Steinberg, 2006., prema Buljan Flander, Jelić Tuščić i Matešković, 2014.).

Djeca izložena roditeljskim sukobima osjećaju se nemoćno. Iz straha prikrivaju neslaganje s otuđiteljem i ugađaju svima, što može rezultirati regresijom ili agresijom (Steinberg, 2006., prema Buljan Flander, Jelić Tuščić i Matešković, 2014.). Kada godinama kasnije shvate što se dogodilo, neka otuđena djeca zamjeraju otuđitelju što može dovesti do prekida odnosa i s tim roditeljem (ConwayRand, 1997.a).

\section{Obilježja otuđitelja}

Vjerojatnije je da će otuđitelj imati znakove kontrolirajućeg i prisilnog ponašanja, slabo reguliranog gnjeva, paranoične crte, te stil roditeljstva koji potiče ovisne odnose između roditelja i djece (Garber, 2011.; Johnston i sur., 2005.; Kopetski, 1998., prema Warshak, 2015.). Kod otuđitelja je često izražena ljutnja, problemi s granicama, teške separacijske tjeskobe i identifikacija s djetetom (Kelly i Johnston, 2001.).

Kopetski (1998.b) je s Purcell utvrdila sljedeće karakteristike otuđitelja: narcisoidnost ili paranoidnost u interakcijama kao rezultat poremećaja osobnosti, perfekcionizam, eksternalizacija te naglašena ljutnja i odsustvo tuge.

Siegel i Langford (1998., prema Bernet i sur., 2010.) utvrdili su da je vjerojatnije da će otuđitelj koristiti obrambene mehanizme negiranja i projekcije. Baker (2007.b, prema Bernet i sur., 2010.) je utvrdila da su mnogi otuđitelji imali poremećaje osobnosti, bili zlostavljači i koristili tehnike slične onima vođa kultova. Gordon i sur. (2008., prema Bernet i sur., 2010.) utvrdili su da su otuđitelji skloniji obrambenom mehanizmu projekcije i crno-bijelom načinu razmišljanja. 


\section{Obilježja otuđenog roditelja}

Prema Kopetski (1998.b), otuđeni roditelj je pasivan i češće popušta u sukobima, što može biti crta osobnosti, ali i prilagodba na bračni odnos s kontrolirajućim partnerom. Ako partner ne tolerira mane ni različita mišljenja ili je sklon optuživanju, pasivni partner to tolerira i počinje sumnjati u sebe. Otuđeni roditelji zbog toga ponekad pate od depresije ili anksioznosti, zbog čega djeluju psihički manje zdravi (Kopetski, 1998.b). No, prema Conway Rand (1997.b), otuđeni roditelji lažno optuženi za zlostavljanje kod promjene odluke o povjeri ocijenjeni su sposobnijima za uspostavu i održavanje zdrave veze između roditelja i djeteta. Prema Kelly i Johnston (2001.), otuđeni roditelji često gube empatiju za dijete te su mu manje emotivno dostupni i kad se opravdano žali, čime doprinose produbljivanju otuđenja. Kopetski je temeljem iskustva u svom radu zaključila da je otuđeni roditelj fleksibilniji, te spremniji suočiti se s osobnim problemima i rješavati ih (Rand, Rand, R. i Kopetski, 2005.).

\section{PROCJENA OTUĐENJA}

Procjena otuđenja uključuje utvrđivanje je li u određenom slučaju riječ o otuđenju, a ako se isto potvrdi, potrebno je utvrditi uzroke, odnosno vrstu otuđenja kako bi se sukladno tome moglo pristupiti rješavanju problema.

Prema Kelly i Johnston (2001.), ključno je razlikovati djecu otuđenu od roditelja od djece koja odbijaju kontakte $s$ drugim roditeljem zbog opravdanih ili razvojno očekivanih razloga. Za procjenu otuđenja od roditelja potrebno je prvo procijeniti odnos djece s roditeljima na kontinuumu od pozitivnog do negativnog: od pozitivnih odnosa s oba roditelja, preko sklonosti jednom roditelju, saveza s jednim roditeljem (djeca koja preferiraju jednog roditelja i ambivalentna su prema drugom) i udaljavanja od drugog roditelja zbog opravdanih razloga (nasilja, zlostavljanja, ovisnosti...), do otuđenja od roditelja (Kelly i Johnston, 2001). Rueda (2003., 2004., prema Bernet i sur., 2010.) je utvrdio visok stupanj pouzdanosti procjene otuđenja od roditelja temeljem osam znakova otuđenja prema Gardneru.

Bala (2012., prema Woodall, 2014.) je razvio podjelu na hibridno i čisto otuđenje. Hibridnim otuđenjem smatra slučajeve u kojima roditeljski sukob i njihove međusobne razlike dovode do toga da dijete ne može zadržati blizak odnos s oba roditelja. Čisto otuđenje odnosi se na slučajeve u kojima jedan roditelj namjerno izaziva otuđenje djeteta od drugog roditelja. Čisto otuđenje dalje dijeli na: svjesno, kada otuđitelj shvaća što čini i nesvjesno, kada otuđitelj zbog svog psihičkog stanja ne može shvatiti da je to što čini loše.

Prema Drozd i Olesen (2004.), kada u istom slučaju postoje navodi o zlostavljanju i otuđenju, bitno je imati okvir za organizaciju različitih hipoteza, kako bismo izbjegli 
preuranjen završetak analize i spriječili utjecaj predrasuda ili neznanja na zaključak. Oni nude takav okvir koji nazivaju »drvo odluke« (Drozd, Olesen i Kleinman, 2000., prema Drozd i Olesen, 2004.), a sastoji se od aspekata obiteljskog funkcioniranja koje treba uzeti u obzir. Prvo se postavlja pitanje ima li dijete u osnovi pozitivan odnos s roditeljima te odgovara li djetetovo ponašanje njegovoj dobi i stupnju razvoja. Potom se postavlja pitanje je li dijete trenutno sigurno. U slučaju sumnje na zlostavljanje, prvo treba procijeniti neposredne faktore djetetove sigurnosti te u slučaju potrebe obavijestiti centar za socijalnu skrb o mjerama nužnim za osiguravanje iste. Potom se ispituje zašto odnos između djeteta i roditelja nije pozitivan i zašto dijete ima probleme u ponašanju. Sve hipoteze treba potpuno i neovisno ispitati prije donošenja zaključka.

Za procjenu otuđujućeg ponašanja treba utvrditi vjeruje li otuđitelj u ono što govori o drugom roditelju; je li iskreno zabrinut za dijete; postoji li neka dobit koja bi objasnila njegovo ponašanje; postoji li povijest odbijanja u obitelji; ima li roditelj i zašto probleme s jasnim razmišljanjem te vidi li dijete kao produžetak sebe. Ako se utvrdi da je odbačeni roditelj adekvatan kao roditelj, a drugi se roditelj trudi okrenuti dijete protiv njega, to se mora istražiti kao moguće otuđenje. Ako se pak kod djeteta primijete znakovi otuđenja, treba razmotriti različite moguće uzroke takvog ponašanja.

Stručnjak treba ostati neutralan tijekom prikupljanja podataka, postavljanja hipoteza i njihovog testiranja. Drvo odluke opisuje moguć raspon utjecaja na dijete uzevši u obzir varijable na strani djeteta, te roditeljsko ponašanje i odgojne stilove (Drozd i Olesen, 2004.). 


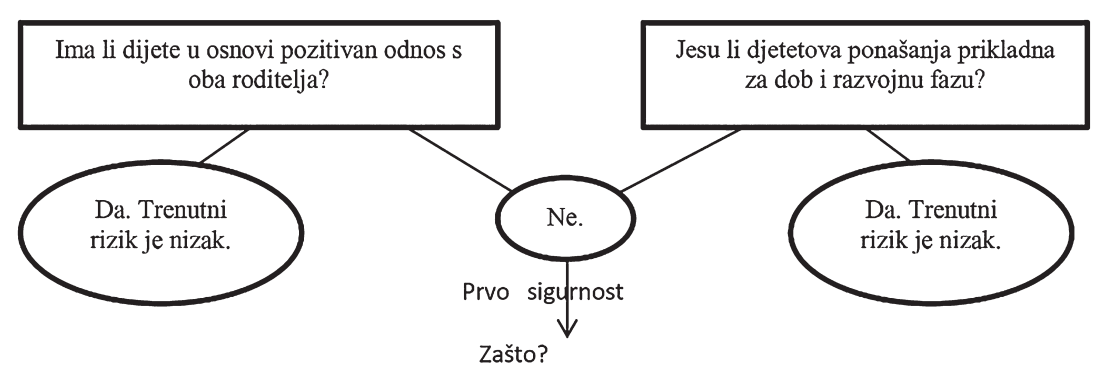

Ispitivanje različitih hipoteza

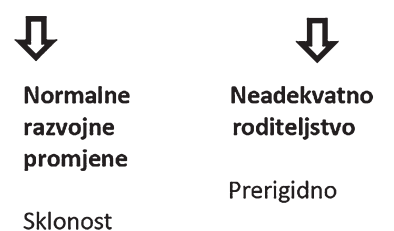

Prepopustljivo

Savez

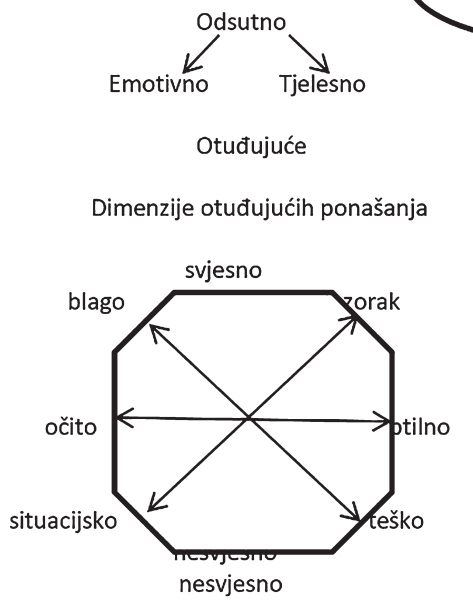

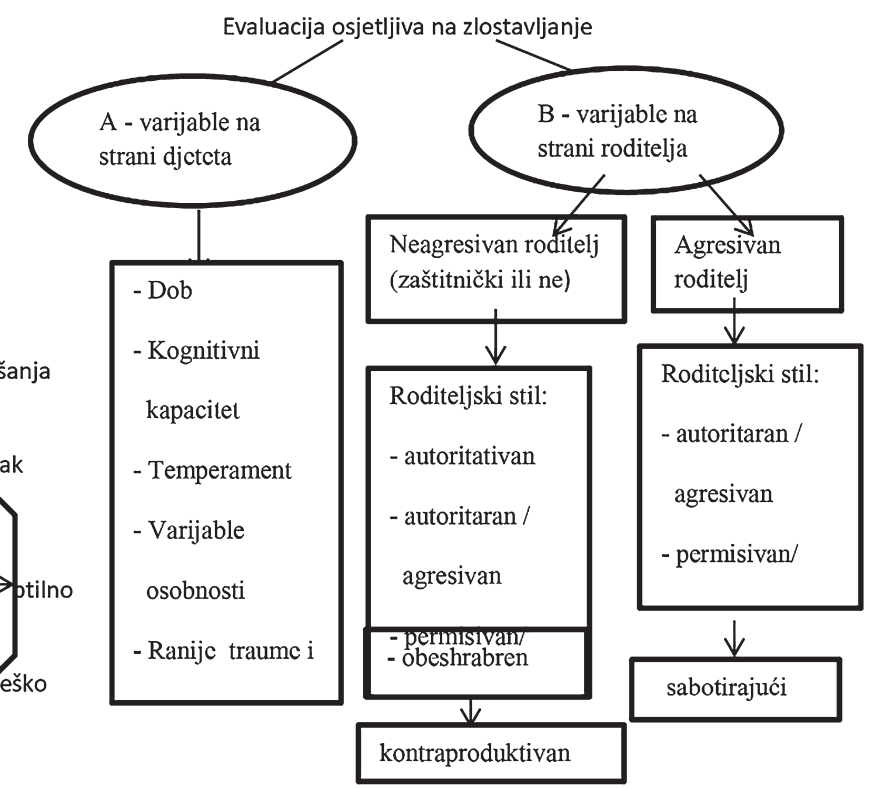

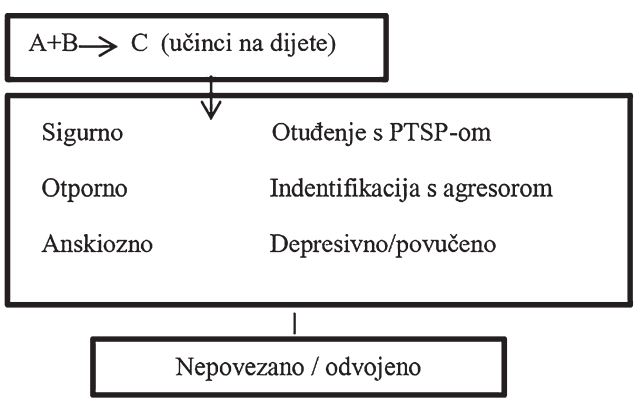

Slika 1. "Drvo odluke« (Drozd i Olesen, 2004.: 100) 


\section{TRETMAN OTUĐENJA OD RODITELJA}

Prema Kelly i Johnston (2001.), kompleksnost otuđenja zahtijeva cjelovitu procjenu za razumijevanje faktora koji su doveli do otuđenja kod određenog djeteta, temeljem čega se može izraditi učinkovit plan pravnih i terapeutskih intervencija za njegovo prevladavanje. Prema Warshak (2008.), preduvjet za zaustavljanje i otklanjanje otuđenja od roditelja je uspostava i održavanje kontakata drugog roditelja s djetetom, a postupno uvođenje kontakata s otuđenim roditeljem nije se pokazalo djelotvornim. U slučajevima otuđenja, pri promjeni odluke o povjeri treba uzeti u obzir i druge faktore bitne za dobrobit djece. U nekim obiteljima uputno je dijete za početak smjestiti u drugo okruženje koje olakšava kontakte s otuđenim roditeljem i ograničava kontakte s otuđiteljem (Warshak, 2008.).

Warshak (2008.) otuđenim roditeljima daje smjernice kako pristupiti otuđenoj djeci. Ne smiju ih odmah razuvjeravati, već im pristupiti neizravno (gledanje filma koji prenosi ideje koje otuđena djeca trebaju naučiti kao uvod u razgovor ili preko druge osobe koju dijete poštuje). Neutralnoj djeci treba pomoći da takva i ostanu te ih poučiti kako reći roditeljima da ne žele biti uključena u roditeljski sukob. Otuđenoj djeci treba pomoći da shvate da nitko nije savršen i potaknuti ih da sama razmisle jesu li otuđiteljeve optužbe opravdane. Otuđeni roditelj treba razmotriti moguću utemeljenost optužbi, bolje se upoznati s potrebama i interesima djece i stvoriti okruženje u kojem se ona osjećaju ugodno i u kojem će lakše uvidjeti neutemeljenost ocrnjivanja. Otuđeni roditelj može bivšeg partnera kritizirati samo ako je siguran da je to primarno radi dobrobiti djeteta, i to na način da se maksimalno očuva pozitivna slika djeteta o tom roditelju. Ako su djeca previše otuđena, te su iscrpljene sve mogućnosti za prevladavanje otuđenja, a terapeut savjetuje otpuštanje, razumno je da roditelj prihvati privremeni prekid odnosa s otuđenim djetetom (Warshak, 2008.).

\section{Terapija otuđenja od roditelja}

Ako su djeca u središtu sukoba, izložena manipuliranju, imaju kronične smetnje (strahovi, tuga, problemi u učenju/ponašanju/spavanju, psihosomatizacije), pokazuju manjak poštovanja i smanjenje privrženosti ili odbijaju kontakte, uputno je konzultirati terapeuta (Warshak, 2008.). Jaffe, Ashbourne i Mamo (2010.) navode da pravodobna reakcija stručnjaka može usmjeriti roditelje na potrebe i interese djeteta te time spriječiti otuđenje. U slučajevima otuđenja smatraju ključnim da sud odredi sankcije u slučaju nesuradnje, a u slučajevima teškog otuđenja promijeni odluku o povjeri uz intenzivnu terapiju. 
Prema Warshak (2008.), dobar terapeut unosi neutralnu perspektivu u sukob. Pomaže članovima obitelji shvatiti potrebe i osjećaje, prilagoditi se i uspostaviti izravne komunikacijske veze. Terapeut koji radi s djetetom štiti od zlostavljanja i lažnih optužbi o istom, a poželjniji je od kontakata u nazočnosti treće osobe koji djetetu poručuju da je opasno biti s otuđenim roditeljem (Warshak, 2008.).

Prema Warshak (2008.), terapija s otuđiteljima otkriva motive za otuđivanje te omogućuje rješavanje ljutnje. Pomaže im razgraničiti vlastite od osjećaja djece, pronaći dobroćudnija objašnjenja ponašanja otuđenog roditelja, uvidjeti svoje destruktivno ponašanje i popraviti štetu. Poučava ih o dugoročnoj šteti otuđenja za djecu. Otuđene roditelje terapeut poučava o otuđenju i kako mu se suprotstaviti, u čemu im pruža podršku, kao i u eventualno potrebnom otpuštanju. Ako je otuđeni roditelj doprinio otuđenju, pomaže mu unaprijediti roditeljske vještine (Warshak, 2008.).

Otuđenoj djeci terapeut pomaže da se isključe iz roditeljskog sukoba i postignu realističniju sliku roditelja. Ukazuje im na razlike među ljudima, potiče da sama prosude točnost optužbi otuđitelja, te ih uči kako se suprotstaviti manipuliranju. Terapija djelovanjem na uzroke problema uz pravu dozu empatije i suočavanja kod svih aktera potiče promjenu ponašanja (Warshak, 2008.).

Prema Warshak (2008.), uputno je da oba partnera sudjeluju u izboru terapeuta. Ako se oni ne mogu dogovoriti, terapeuta može odrediti centar za socijalnu skrb. Ako ne surađuju, centar o tome obavještava sud, odnosno državno odvjetništvo. Dok dijete živi s otuđiteljem koji ne prepoznaje ili odbija rješavati problem, terapeut je nemoćan i mora na svojoj strani imati snagu zakona da bi mogao utjecati na promjenu (Warshak, 2008.). Erwoine (2005., prema Bernet i sur., 2010.) smatra da je ključ uspjeha u kombiniranju psihoterapeutskog tretmana sa sudskim mjerama.

Terapija u ovakvim slučajevima uključuje odstupanje od načela povjerljivosti jer terapeut može svjedočiti na sudu. To može utjecati na roditelje da primjerenije postupaju kako bi se predstavili u boljem svjetlu, što može pomoći djeci (Warshak, 2008.).

Bolje je da jedan terapeut radi s cijelom obitelji jer u protivnom može izgubiti objektivnost. Terapeut mora razumjeti gledište svakog člana obitelji, pomoći njihovom međusobnom razumijevanju te poticati promjene stavova i zdravije funkcioniranje obitelji. Ako s članovima obitelji rade posebni terapeuti, oni moraju međusobno surađivati kako ne bi prihvatili iskrivljeno viđenje stvarnosti članova obitelji i tako pridonijeli problemu (Warshak, 2008.).

Warshak (u tisku, prema Warshak, 2015.) ističe da edukativni programi trebaju naglasiti važnost odnosa djece s oba roditelja za njihov zdrav razvoj i socijalizaciju te educirati roditelje kako i zašto izbjegavati otuđujuća ponašanja i uključivanje djece u sukob.

Garrity i Baris (1994., prema Bernet i sur., 2010.) uveli su koncept roditeljskih koordinatora koji prilagođavaju plan susreta i druženja svakom slučaju na način koji 
reducira sukob i pomažu roditeljima da ga provode. U slučajevima blagog otuđenja pomažu roditeljima da konstruktivnije komuniciraju i praktično ih savjetuju. U slučajevima umjerenog otuđenja uz sastanke s roditeljskim koordinatorom nužna je i intenzivna terapija.

Woodall (2014.) smatra da je sudska prisila nužna za postizanje promjene za koju je uvjet što prije ponovno uspostaviti odnos djeteta s otuđenim roditeljem. Kada su djeca izdvojena od otuđitelja koji njima svjesno manipulira, može biti nužno ograničiti mu kontakt s djecom dok se radi na obnovi odnosa djece s otuđenim roditeljem (Woodall, 2012., prema Woodall, 2014.). Woodall (2014.) smatra nužnim paralelno raditi s otuđenim roditeljem na usvajanju novih roditeljskih pristupa. Cilj mora biti postizanje uravnoteženog odnosa među roditeljima. Ako otuđitelj nije svjestan da čini nešto loše, treba razmotriti mogućnost poremećaja osobnosti. Takvi slučajevi zahtijevaju brzu promjenu odluke o povjeri (Bala, 2012., prema Woodall, 2014.). Ako je pak otuđitelj svjestan da je to što čini loše, Woodall (2014.) preporučuje privremenu promjenu odluke o povjeri uz edukaciju, roditeljsku koordinaciju i terapiju obiteljskog sustava. Pristup svakom slučaju osmišljava se individualno nakon pomne procjene. Stručnjaci najčešće odlaze kući kod roditelja kako bi se što ranije u procesu uspostavio kontakt djeteta s otuđenim roditeljem u sigurnom i podržavajućem okruženju. Woodall (2018.) smatra da prvi korak mora biti utvrđivanje uzroka otuđenja kod svakog pojedinog djeteta. Terapija se provodi nakon ponovne uspostave odnosa djeteta i otuđenog roditelja, bez čega ne može imati uspjeha (Woodall, 2018.).

\section{Uloga suda i centra za socijalnu skrb}

Bitno je da su svi uključeni stručnjaci upoznati s otuđenjem od roditelja te da ga uzmu u obzir kao jednu od alternativa pri procjeni slučaja. U protivnom, skriveni motivi i suptilne manipulacije otuđitelja mogu proći neprimijećeno. Potrebno je opsežno ispitati čimbenike koji su doveli do otuđenja od roditelja, među njima i mogućnost sustavnog otuđivanja od strane otuđitelja (Warshak, 2008.).

Warshak (2008.) navodi da centar za socijalnu skrb, odnosno sud treba odrediti točan raspored kontakata djeteta s roditeljem s kojim ne živi, zabraniti zadiranje u vrijeme s njim, jasno odrediti mjesto i način odvijanja kontakata, neutralna mjesta preuzimanja djeteta, metode niske razine sukoba za razmjenu bitnih informacija o djeci, postupak promjene plana, mehanizam praćenja te posljedice nepoštovanja plana. Ako otuđitelj uporno ometa kontakte djece s drugim roditeljem, sud mu može ograničiti kontakte s djetetom, a dijete povjeriti drugom roditelju. Sama ta mogućnost može potaknuti promjenu ponašanja kod otuđitelja (Warshak, 2008.).

Centar za socijalnu skrb prikuplja socioanamnestičke podatke, vrši obvezno savjetovanje i psihološku obradu stranaka i potom daje prijedlog sudu s kojim će 
roditeljem dijete živjeti i kako će se odvijati kontakti s drugim roditeljem, vodeći pri tom računa o najboljem interesu djeteta. Centar po potrebi izriče i mjere obiteljsko-pravne zaštite, predlaže sudu izmjenu odluke o povjeri, pokreće kaznene postupke protiv roditelja, a članovi tima mogu i svjedočiti na sudu. Prema Warshak (2008.), pri prikupljanju socioanamnestičkih podataka u slučajevima otuđenja od roditelja ili optužbe za isto važno je da stručnjak bude nepristran, te da:

- pažljivo ispita povijest obiteljskih odnosa

- izravno promatra oba partnera s djecom i daje im vremena da kažu što žele

- razgovara s ljudima koji poznaju obitelj

- točno primjenjuje i tumači testove

- ozbiljno razmatra mogućnost otuđenja od roditelja

- nastoji premostiti potencijalne učinke manipulacije na djecu

- pažljivo procjenjuje optužbe za zlostavljanje i nasilje

- nastoji shvatiti čimbenike koji su doveli do otuđenja

- uviđa prednosti i nedostatke oba roditelja i važnost odnosa djece s oba roditelja

- razmatra alternativna tumačenja svoje procjene i uzima u obzir sve informacije

- izvlači zaključke iz prikupljenih informacija i temeljem njih daje preporuke.

Pravni sustav često podržava otuđenje od roditelja odugovlačenjem postupka i odsustvom sankcija za otuđiteljeve manipulacije. Da bi se to promijenilo, potrebno je eliminirati nedorečenosti u zakonu, donositi jasne sudske odluke koje će precizno definirati susrete te dosljedno primjenjivati sankcije predviđene u slučaju nepoštivanja tih odluka (Turkat, 1999.).

Jaffe, Ashbourne i Mamo (2010.) navode da se dugotrajni postseparacijski roditeljski sukob može reducirati samo kroz ranu kliničko-legalnu intervenciju koja koristi autoritet suda i uvid stručnjaka da formulira i provede intervencijski plan. Važno je da sud jasno navede sankcije za nepoštovanje svojih odluka, prati uključivanje u preporučene usluge koje moraju biti dostupne te sankcionira nesuradnju. Nagli prekid odnosa s otuđiteljem može biti traumatičan za dijete jer narušava njegov osjećaj sigurnosti pa treba uložiti više napora u rano otkrivanje i intervenciju (Jaffe, Ashbourne i Mamo, 2010.).

Gardner, Kelly i Johnston (prema Warshak, 2003.) za tretman otuđene djece preporučuju sudski naložen tretman uz prisilne kontakte između djeteta i otuđenog roditelja, te sankcije za nepridržavanje sudskih odluka.

Conway Rand (1997.b) navodi primjer suca Nakahare iz Kalifornije koji smatra da držanje roditelja odgovornima vodi uspjehu, a odsustvo sankcija neuspjehu jer učvršćuje roditelje u uvjerenju da mogu činiti što žele. Nakahara je izricao novčane i zatvorske kazne za propušten termin terapije, kašnjenje pri predaji djeteta drugom 
roditelju i slično. Kad blaže sankcije nisu dale rezultata primjenjivao je zatvorsku kaznu, za koju smatra da je optimalna u trajanju od pet dana (ConwayRand, 1997.b).

Preporuke u slučaju nesuradnje otuđitelja su jasne: dijete treba povjeriti otuđenom roditelju (Vestal, 1999.), što je i jedini dokazani način otklanjanja teškog otuđenja od roditelja (Gardner, 1992.; Clawar i Rivlin, 1991.; Dunne i Hedrick, 1994., prema Vestal, 1999.).

\section{Tretman otuđenja od roditelja ovisno o vrsti otuđenja}

Prema Gardneru (1991.), u slučajevima teškog otuđenja tradicionalna terapija nije moguća pa djecu prije učinkovitog tretmana treba smjestiti kod otuđenog roditelja, po potrebi pod prijetnjom sankcijama i/li putem prijelaznog smještaja u vidu hospitalizacije. Nakon nekoliko tjedana sukladno procjeni stručnjaka postupno se uvode kontakti s otuđiteljem.

U slučajevima umjerenog otuđenja, ako se uz stručnu pomoć uspostave kontakti s otuđenim roditeljem, nema potrebe za promjenom odluke o povjeri. Ako je odnos djeteta s otuđenim roditeljem prije bio topao, otuđenje je često samo površinsko. Za otuđenu djecu posebno je kritična primopredaja u prisutnosti otuđitelja jer im to pojačava sukob lojalnosti pa se opiru. Kod otuđenog roditelja dijete se opušta i omogućuje mu se odnos s tim roditeljem kojeg više ne doživljava prijetećim.

U slučajevima blagog otuđenja roditelji poduzimaju blage oblike manipuliranja djecom da bi učvrstili svoj položaj, a djeca postaju ambivalentna prema susretima s drugim roditeljem. Sudska presuda kojom se dijete povjerava otuđitelju obično prekida ovaj oblik otuđenja (Gardner, 1991.). Darnall (2013., prema Boch-Galhau, 2018.) navodi da se blago otuđena djeca mogu distancirati od ocrnjivanja te, iako odbijaju kontakt s otuđenim roditeljem, uživaju u njemu kad se isti uspostavi.

\section{Rezultati istraživanja učinkovitosti intervencija}

Do sada je proveden niz istraživanja učinkovitosti intervencija primijenjenih u slučajevima otuđenja od roditelja, te je potrebno s time nastaviti u svrhu razvoja učinkovitog tretmana. Clawar i Rivlin (1991., prema Warshak, 2003.) su na uzorku od 700 slučajeva otuđene djece utvrdili da je povećanje učestalosti kontakata s otuđenim roditeljem najučinkovitije u poništavanju otuđenja. Clawar i Rivlin (1991., prema Vestal, 1999.) utvrdili su da je $80 \%$ djece željelo da se »ispiranje mozga« prekine te da se njihovo izraženo mišljenje često razlikovalo od njihovih stvarnih želja. Zaključili su da za većinu otuđitelja savjetovanje i edukacija nisu prikladne intervencije jer ne preuzimaju odgovornost (Vestal, 1999.). Clawar i Rivlin (1991., prema Rand, Rand, 
R. i Kopetski, 2005.) utvrdili su nedjelotvornost terapije uz postupno uvođenje kontakata s otuđenim roditeljem, koja ponekad i pogoršava stanje, a sudovi su oklijevali poduzeti odlučnije mjere dok se stanje nije znatno pogoršalo.

Dunne i Hedrick (1994., prema Warshak, 2003.) su na uzorku od 16 slučajeva teškog otuđenja od roditelja utvrdili da je otuđenje uklonjeno u sva tri slučaja u kojima je sud djecu povjerio otuđenom roditelju i/ili strogo ograničio kontakt djece s otuđiteljem. U ostalim slučajevima provedena je terapija uz postupno povećanje kontakata s otuđenim roditeljem te je u dva slučaja došlo do minimalnog poboljšanja, u 9 nije bilo promjene, a u dva je došlo do pogoršanja.

Gardner (2001., prema Warshak, 2003.) je na uzorku od 99 otuđene djece utvrdio da je otuđenje smanjeno ili uklonjeno u svim slučajevima (22) u kojima je dijete sudskom odlukom povjereno otuđenom roditelju ili je povećan kontakt s njim. Otuđenje je pak smanjeno samo kod 9\% (7/77) djece kojoj sud nije povećao kontakte s otuđenim roditeljem, te su ona ostala izložena otuđiteljevom utjecaju.

\section{POTEŠKOĆE U STRUČNOM RADU U SLUČAJEVIMA OTUĐENJA OD RODITELJA}

Prema Conway Rand (1997.b), stručnjak koji ima kontakt samo s jednom stranom, a nema znanja o otuđenju, može izgubiti objektivnost i podržati ideju da dijete treba štititi od otuđenog roditelja. Stručnjaci moraju uvijek imati na umu da predugo trajanje postupka produbljuje otuđenje od roditelja te lažne optužbe često samo tome i služe. Stoga je potrebno, kad je utvrđeno otuđenje, brzo donijeti odluku koja može zaustaviti proces otuđenja, posebno ako uključuje promjenu odluke o povjeri i sankcije u slučaju nastavka otuđujućeg ponašanja (Cartwright, 1993.).

Warshak (2015.) izdvaja najčešće zablude stručnjaka o otuđenju s kojima se sreo, a koje su suprotne nalazima istraživanja i njegovom dugogodišnjem iskustvu:

- djeca se nikad ne otuđe od roditelja s kojim provode najviše vremena, no Warshak je radio na 50 slučajeva u kojima je otac tijekom kontakata otuđio djecu od majke s kojom su živjela

- nikad ne dolazi do otuđenja od majke, no istraživanja (Bala i sur., 2010.; Kopetski i sur., 2006.; Berns, 2001.; Gardner, 2002., prema Warshak, 2015.) su pokazala da su djeca otuđena od majke u 1/3 - 1/2 slučajeva

- svaki roditelj jednako doprinosi otuđenju, no treba uzeti u obzir važnost prošlog odnosa između otuđenog roditelja i djece. Potrebno je, primjerice, utvrditi jesu li mane zbog kojih dijete odbacuje roditelja postojale i prije otuđenja 
- otuđenje je djetetova kratkoročna reakcija, no Warshak (2010.b, prema Warshak, 2015.) je utvrdio prosječno trajanje otuđenja od 2,5 godine, s time da prije intervencije ni u jednom slučaju nije bilo znakova poboljšanja

- ne treba ništa poduzeti kod mlađe djece koja se opiru pri prelasku k drugom roditelju, a izvan utjecaja otuđitelja iskazuju mu privrženost, no bez intervencije otuđujuće ponašanje nastavlja negativno utjecati na dijete i njegov odnos s drugim roditeljem

- mišljenje otuđenih adolescenata mora se poštovati, no oni su skloni nezrelim prosudbama i ponašanju te trebaju autoritet roditelja i suda, strukturu i granice jednako i/ili više nego mala djeca

- otuđena djeca koja nemaju problema u drugim područjima života mogu sama odlučiti o kontaktu s drugim roditeljem, no otuđenje je i samo značajan problem pa i prividno dobro prilagođenoj djeci, kao i roditeljima, treba pomoći da ga prevladaju

- otuđenje od roditelja najbolje se tretira klasičnom terapijom dok dijete nastavlja živjeti s otuđiteljem, no nema dokaza da je ova metoda pomogla u prevladavanju ili smanjenju teškog otuđenja dok dijete nema kontakt s otuđenim roditeljem. Teško otuđenje smanjeno je kod djece koja su povjerena otuđenom roditelju na duži period. Warshak (2015.) smatra da stručnjak umjesto bavljenja dječjim prigovorima roditelju, djecu treba poučiti o negativnim stereotipima, selektivnoj pažnji, iskrivljenim percepcijama i sjećanjima, različitim perspektivama, kritičkom razmišljanju, učinkovitoj komunikaciji, rješavanju sukoba, te važnosti oba roditelja za dijete.

- odvajanje djece od otuđitelja je traumatično, ali baš naprotiv: djeca koja se na neko vrijeme smjeste kod otuđenog roditelja bez iznimke postižu napredak (Warshak, 2015.).

Navedene poteškoće često se susreću i u radu stručnjaka centara za socijalnu skrb u Hrvatskoj. Otuđitelji se pozivaju na općeprihvaćene vrijednosti poput zaštite djece, s kojima svi suosjećamo i koje smo dužni štititi. U odsustvu adekvatne edukacije, vremena da se slučaj pomnije preispita (uslijed preopterećenosti djelatnika centra za socijalnu skrb, te dužnosti postupanja bez odgode u slučaju prijave zlostavljanja), kao i zbog nedovoljne zastupljenosti supervizije u okviru koje bi pomnije preispitali vlastite procjene i odluke, stručnjaci mogu djelovati neadekvatno. 


\section{ULOGA OBITELJSKE MEDIJACIJE U PROCJENI I TRETMANU OTUĐENJA OD RODITELJA}

Sudski postupak usmjerenošću na pobjedu produbljuje roditeljski sukob (Teyber, 2001.). Da bi prekinuli kronični sukob, roditelji moraju komunicirati uz uzajamno uvažavanje te ostati usmjereni na problem i postizanje sporazuma. Stoga je poželjno pokušati riješiti spor u obiteljskoj medijaciji gdje se roditelje usmjerava na sagledavanje potreba djece i izradu plana roditeljske skrbi koji najbolje odgovara istima. Tako se smanjuje intenzitet sukoba jer roditelji, uz strukturiranu pomoć obiteljskog medijatora, sami izrađuju plan roditeljske skrbi, čime se minimizira osjećaj gubitka svakog roditelja.

Prema Hellblom Sjogren (2002.), stručnjaci pomažućih profesija često se identificiraju s roditeljem koji traži pomoć i tako u namjeri da zaštite dijete doprinose otuđenju. Tu se načelo nepristranosti obiteljskog medijatora pokazuje kao vrijedno i za ostale stručnjake.

Obiteljski medijator ulazi u proces na samom početku, kada roditelji pokrenu brakorazvodni postupak. Razgovara s oba roditelja pa tako stječe širu sliku i može, ako je educiran o otuđenju, već na predmedijaciji primijetiti prve znakove istog i adekvatnom reakcijom spriječiti njegov daljnji razvoj.

Prema Vestal (1999.), obiteljski medijator mora biti obučen prepoznati skrivene motive i nositi se s otuđujućim taktikama. Obiteljski medijatori moraju imati saznanja o tretmanu otuđenja kako bi mogli bez odgađanja uputiti roditelje stručnjaku koji će raditi na rješavanju problema. Tako mogu pridonijeti kroz ranu identifikaciju problema i ograničavanje njegova negativnog utjecaja. U protivnom, mogu raditi na postizanju plana zajedničke roditeljske skrbi, čime se u slučajevima teškog otuđenja gubi vrijeme tijekom kojeg otuđitelj nastavlja »ispirati mozak« djeci (Vestal, 1999.).

Prema Vestal (1999.), zasebna predmedijacijska trijaža radi identificiranja slučajeva u kojima su nužne druge intervencije prije provođenja obiteljske medijacije smanjila bi potrebu za visokom razinom obuke obiteljskog medijatora za postupke procjene. Cjelovita inicijalna procjena slučajeva dovodi do smanjenja pruženih usluga (identificiranjem poremećaja osobnosti kao korijena problema, preskaču se edukacija i obiteljska medijacija kao neprikladne intervencije) i povećanja broja postignutih sporazuma (Kulak i sur., 2008., prema Jaffe, Ashbourne i Mamo, 2010.). Saposnek (1998., prema Vestal, 1999.) preporučuje da obiteljski medijator utvrdi stupanj otuđenja i prikladnost za medijaciju te sukladno utvrđenom odluči o daljnjim intervencijama (Vestal, 1999.).

Prema Vestal (1999.), nužna je i sigurnost da će sud donijeti brze, jasne odluke da obeshrabri otuđujuća ponašanja. Obiteljski medijator mora balansiranjem moći 
kompenzirati neravnotežu moći u situaciji u kojoj je otuđeni roditelj u nepovoljnijem položaju, pazeći pri tom na poštovanje načela nepristranosti. Nužno je osigurati mehanizam upravljanja manipulativnim ponašanjem te praćenje pridržavanja sudskih naloga i/ili koraka dogovorenih u medijaciji.

Vestal (1999.) preporučuje da se obiteljska medijacija u slučajevima otuđenja radi u suvoditeljstvu medijatora suprotnog spola i profesija iz područja psihologije i prava. Obiteljski medijator u ovakvim slučajevima mora imati znanja iz područja mentalnog zdravlja i obiteljskog prava te komunikacijske vještine za poticanje povjerenja i suradnje među zavađenim stranama. Preporučljiva su i dodatna znanja za otkrivanje otuđenja, utvrđivanje stupnja štete te razvoj prikladnog tretmana (Vestal, 1999.).

U blagim i umjerenim slučajevima otuđenja od roditelja obiteljska medijacija može biti uspješna, dok je teške slučajeve otuđenja potrebno bez odgađanja uputiti na sud jer je u takvim obiteljima nužna intenzivna terapija uz potporu autoriteta suda (Vestal, 1999.).

U slučajevima hibridnog otuđenja kojem su doprinijela oba roditelja, Woodall (2012., prema Woodall, 2018.) preporučuje kombinaciju obiteljske terapije, terapeutske medijacije i roditeljske koordinacije uz podršku suda. Takav tretman obično traje od 6 do 12 mjeseci, a kontakt djeteta s otuđenim roditeljem uvodi se tijekom prva 3 mjeseca intervencije. Kako su u slučajevima otuđenja prisutni psihički problemi kod jednog ili oba roditelja, nužna je prisila za postizanje promjene pa je autoritet suda nužan, osobito radi ponovne uspostave kontakta djeteta s otuđenim roditeljem. Ključno je što prije ponovno uspostaviti kontakt djeteta s otuđenim roditeljem, ne čekajući da to otuđeno dijete samo odluči jer do toga dolazi vrlo rijetko (Niery, 2011., prema Woodall, 2018.)

U slučajevima čistog svjesnog otuđenja treba privremeno povjeriti dijete otuđenom roditelju, a otuđitelju ograničiti kontakt s djetetom dok se kroz edukaciju, obiteljsku terapiju i roditeljsku koordinaciju, radi na obnovi odnosa djeteta s otuđenim roditeljem, kao i na promjeni ponašanja otuđitelja (Woodall, 2012., prema Woodall, 2018.). U slučajevima čistog nesvjesnog otuđenja često je prisutan poremećaj osobnosti kod otuđitelja, te je tad nužna promjena odluke o povjeri (Bala, 2012., prema Woodall, 2018.).

\section{Iskustva aktualne prakse u Hrvatskoj}

Sustav neadekvatnim intervencijama i odsustvom sankcija doprinosi razvoju teškog otuđenja. Događa se da stručna mišljenja budu pristrana kada je stručnjak u kontaktu samo s jednom stranom. Sudske presude ne predviđaju sankcije za manipulativno ponašanje, već se u slučaju njihovog nepoštovanja poduzimaju mjere 
poput stručne pomoći i potpore koje u ovakvim slučajevima samo vode daljnjem produbljivanju otuđenja.

Ovrha sudskih rješenja ne provodi se pozivajući se na želje djece, čak i kada je u obrazloženju presude utvrđeno da je dječje odbijanje drugog roditelja rezultat manipuliranja od strane otuđitelja. Otuđitelj je često nazočan pri ovrsi, što djeci dodatno otežava izražavanje mišljenja i eventualno povinovanje sudskoj presudi. $U$ takvoj situaciji njihove izražene želje ni ne mogu biti u skladu s njihovim interesima i potrebama, a vjerojatno niti s njihovim stvarnim željama. Potrebno je imati na umu i da otuđena djeca ne mogu izraziti slobodno formirano vlastito mišljenje. Otuđitelj lažnim prijavama, žalbama, prigovorima, predstavkama i zahtjevima za izuzeće službenih osoba može bez sankcija maksimalno produžiti postupak koristeći tako dobiveno vrijeme za poticanje i produbljivanje otuđenja kod djece. Sustav na to nema primjeren odgovor. Nužno je da sud zaprijeti sankcijama te ih i primijeni u slučaju nepoštovanja sudskih odluka, a kako bi se osigurala njihova provedba. Ovrha rješenja o povjeri djece treba biti provedena bez odgađanja kroz mjeru stručne pomoći i potpore, bez nazočnosti otuđitelja i prebacivanja tereta odluke na djecu

Obiteljska medijacija može dati rezultate u blažim slučajevima otuđenja. U težim slučajevima nisu ni ispunjene pretpostavke za uključivanje u obiteljsku medijaciju zbog neravnoteže moći u korist otuđitelja uslijed njegove bliskosti s djecom, vjerojatnog poremećaja osobnosti ili psihičke bolesti otuđitelja i slično. Vjerojatno je da bi otuđitelj i tražio provedbu medijacije samo kao još jedan oblik manipulacije sustavom: da dobije na vremenu, te je takve slučajeve bolje odmah uputiti na sud.

\section{ZAKLJUČAK}

Djeci je potrebna ljubav, podrška i dostupnost roditelja i šire obitelji, no to im je često uskraćeno kada roditelji uslijed razvoda i međusobnog sukoba izgube iz vida njihove potrebe i interese, dok nadležna tijela to ne prepoznaju i/li nemaju učinkovite mjere protiv takvih štetnih postupaka. Da bi se to promijenilo, potrebno je da svi stručnjaci budu educirani o otuđenju.

lako se obiteljska medijacija u Hrvatskoj tek počela razvijati i nije prikladna intervencija u slučajevima teškog otuđenja od roditelja, nužno je da obiteljski medijatori kao stručnjaci koji među prvima dolaze u kontakt s roditeljima u postupku brakorazvoda budu obučeni o znakovima i tretmanu otuđenja od roditelja kako bi mogli pravodobno i adekvatno reagirati.

Woodall (2014.) smatra da se otuđenje od roditelja u većini slučajeva može otkloniti ako stručnjaci imaju znanje i vještinu, te djeluju odlučno i dosljedno uz podršku suda. Da bi se to postiglo, nužno je: 
- omogućiti stručnjacima pristup spoznajama o otuđenju od roditelja na hrvatskom jeziku

- provesti više istraživanja o uzrocima, posljedicama i tretmanu otuđenja

- sukladno rezultatima istraživanja i postojećoj literaturi utvrditi osnovne smjernice za postupanje.

$\mathrm{Na}$ taj bi se način osposobilo stručnjake za rad u slučajevima otuđenja te bi posljedično sustav mogao pravodobno i adekvatno reagirati, što podrazumijeva provedbu sudskih odluka i uspostavu kontakta djeteta s otuđenim roditeljem kroz interdisciplinarnu suradnju svih stručnjaka uključenih u proces.

\section{LITERATURA}

1. Bernet, W., von Boch-Galhau, W., Baker, J. L. A. \& Morrison, L. S. (2010). Parental alienation, DSM-V i ICD-11. The American Journal of Family Therapy, 38, 76-187.

2. Bernet, W. \& Baker, A. (2013). Parental alienation, DSM-5, and ICD-11: Response to critics. The Journal of the American Academy of Psychiatry and the Law, 41, 98-104.

3. Boch-Galhau, W. (2018). Parental alienation (syndrome) - A serious form of psychological child abuse. Mental Health Fam Med, 13, 725-739. https://doi. org/ 10.1007/s40211-018-0267-0

4. Buljan Flander, G., Jelić Tuščić, S. \& Matešković, D. (2014). Visoko-konfliktni razvodi: Djeca u središtu sukoba. U: Brajša-Žganec, A. i sur. (ur.), Psihološki aspekti suvremene obitelji, braka i partnerstva, 375-394.

5. Cartwright, G. F. (1993). Expanding the parameters of parental alienation syndrome. The American Journal of Family Therapy, 21 (3), 205-215. Preuzeto s: http://citeseerx.ist.psu.edu/viewdoc/download?doi=10.1.1.494.2171\&rep=rep1\&type=pdf (15.6.2017.).

6. Conway Rand, D. (1997a). The spectrum of parental alienation syndrome (Part I). American Journal of Forensic Psychology, 15 (3), 23-50. Preuzeto s: https://pdfs. semanticscholar.org/0b3a/e41199ab07383b6637ec90f404999b669d35.pdf (9.10.2017.).

7. Conway Rand, D. (1997b). The spectrum of parental alienation syndrome (Part II). American Journal of Forensic Psychology, 15 (4). Preuzeto s: https:// pdfs.semanticscholar.org/0b3a/e41199ab07383b6637ec90f404999b669d35. pdf (9.10.2017.).

8. Dijagnostički i statistički priručnik za duševne poremećaje, DSM-5 (2014). Jastrebarsko: Naklada Slap. 
9. Drozd, L. M. \& Williams Olesen, N. (2004). Is it abuse, alienation, and/or estrangement? A decison tree. Journal of Child Custody, 1 (3), 65-106. Preuzeto s: http://www.lesliedrozd.com/articles/DrozdOlesenJCC1(3)2004.pdf (15.6.2017.).

10. Gardner, R. A. (1991). Legal and psychotherapeutic approaches to the three types of parental alienation syndrome families: When psychiatry and the law join forces. Court Review, 28 (1), 14-21. Preuzeto s: https://www.fact.on.ca/ Info/pas/gardnr01.htm (9.10.2017.).

11. Hellblom Sjögren, L. (2002). Predstavljanje roditelja opasnim. SOR u Švedskoj i Norveškoj. Preuzeto s: http://www.udruga-dijete-razvod.hr/clanci/strucniclanci/predstavljanje-roditelja-opasnim-sindrom-otudenja-roditelja-u-svedskoj-i-norveskoj-hellblom-sjogren-lena-phd/ (15.6.2017.).

12. Jaffe, P. G., Ashbourne, D. \& Mamo, A. A. (2010). Early identification and prevention of parent-child alienation: A framework for balancing risks and benefits of intervention. Family Court Review, 48 (1), 136-152. Preuzeto s: http://vawlearningnetwork.ca/sites/default/files/Jaffe\%20Asbourne\%20\%20Mamo\%20 Alienation\%20FCR\%202010.pdf (15.6.2017.).

13. Kelly, J. B. \& Johnston, J. R. (2001). The alienated child: A reformulation of parental alienation syndrome. Family Court Review, 39 (3), 249-266. Preuzeto s : http://jkseminars.com/pdf/AlienatedChildArt.pdf (9.10.2017.).

14. Kopetski, L. M. (1998a). Identifying cases of parent alienation syndrome - Part I. The Colorado Lawyer, 27 (2), 65-68. Preuzeto s: https://www.fact.on.ca/Info/ pas/kopet98a.htm (15.6.2017.).

15. Kopetski, L. M. (1998b). Identifying cases of parent alienation syndrome-Part II. The Colorado Lawyer, 27 (3), 63-66. Preuzeto s: https://www.fact.on.ca/Info/ pas/kopet98b.htm (15.6.2017.).

16. Rand, D., Rand, R. \& Kopetski, L. (2005). The spectrum of parental alienation syndrome (Part III) The Kopetski follow up study. American Journal of Forensic Psychology, 23 (1), 15-43.

17. Teyber, E. (2001). Helping children cope with divorce. San Francisco: Jossey-Bass, A Wiley Imprint.

18. Turkat, I.D. (1999). Divorce-related malicious parent syndrome. Journal of Family Violence 14, 95-97, https://doi.org/10.1023/A:1022874211739

19. Vassiliou, D. \& Cartwright, G. F. (2001). The lost parents' perspective on parental alienation syndrome. The American Journal of FamilyTherapy, 29, 181-191.

20. Vestal, A. (1999). Mediation and parental alienation syndrome: Considerations for an intervention model. Family and Reconciliation Courts Review, 37 (4), 487-503.

21. Warshak, R. A. (2003). Bringing sense to parental alienation: A look at the disputes and the evidence. Family Law Quarterly, 37 (2). Preuzeto s: http://www. warshak.com/pdf/Warshak-CR27-BringingSense.pdf (15.6.2017.). 
22. Warshak, R. A. (2008). Otrov razvoda. Zagreb: Algoritam.

23. Warshak, R. A. (2015). Ten parental alienation fallacies that compromise decisions in court and in therapy. Proffessional Psychology: Research and Practice, 46 (4), 235-249. https://doi.org/10.1037/pro0000031

24. Woodall, K. (2014). Understanding and working with the alienated child. Seen and Heard, 24 (2), 1-9.

25. Woodall, K. (2018). Alienated children and families: Learning from practice. Parental Alienation International, 3(4), 6-8. 
Martina Protulipac

\section{PARENTAL ALIENATION AND FAMILY MEDIATION}

\section{ABSTRACT}

With the increased number and intensity of disputes related to the realisation of parental care, the number of children who, during these procedures, reject one parent and his or her family under the influence of the other parent has also increased. Such behaviour was firstly described by Gardner in 1985 who called it a parental alienation syndrome. Ever since the concept has been developing through contributions from other experts, so that now it is called parental alienation, and its causes, signs and possible treatment approaches have been described in detail. If timely and adequate help is not provided, alienated children may develop problems in social and physical functioning, as well as psychogenic disorders. A family mediator who is trained about this problem can contribute to its early detection and to the provision of adequate help, because he/she can recognise the problem and refer the parents to court without wasting time on family mediation in the cases in which that is an inadequate intervention. The aim of this paper is to present insights into parental alienation and to explain the role of the family mediator in the assessment and treatment of the same.

Key words: parental alienation; family mediation; high-conflict divorce; manipulation, prevention and treatment

\section{(c) (1) 9}

Međunarodna licenca / International License:

Creative Commons Attribution-NonCommercial-NoDerivatives 4.0. 